\title{
EXAMINATION OF THE TYPES OF EROSION AND INTRODUCTION OF PROTECTIVE MEASURES TO PREVENT SOIL LOSS
}

\author{
Mohammad BEYKZADE ${ }^{1}$, Sepide BEYKZADE ${ }^{2}$ \\ ${ }^{1}$ Department of Civil Engineering, Faculty of Engineering, Kharazmi University, Tehran, Iran \\ ${ }^{1}$ M.Beykzade@gmail.com \\ ${ }^{2}$ Faculty of Management, Islamic Azad University Karaj Branch, Karaj, Iran \\ ${ }^{2}$ S.Beykzade2018@gmail.com
}

\begin{abstract}
Soil erosion is the most important challenge of the biosphere. Soil is one of the most important and most valuable natural resources. It meets the essential needs of the world. If the soil is not well preserved, then hunger will conquer all over the globe. This article tried to identify types of erosion and provide solutions to prevent it to protect this main material by examining the effects and results.
\end{abstract}

Key words: Soil erosion, costs, soil preservation, vegetation, pebbles

\section{Introduction}

Over the past fifty years, more than one third of the world's fields have been destroyed by erosion, and it is predicted that this erosion will continue at a rate of 10 million per year. Given the growing population of the planet Earth and reduction of food production potential, the main challenge facing the inhabitants of the earth in the coming years will be the food crisis. A new century can be called the food, water, natural resources and environment crisis, although soil erosion has existed throughout history, its severity has been added in recent years. Following the problem of population, soil erosion is the largest environmental problem of the planet. In the United States, where protective processes are more appropriate, the rate of field soil degradation is 10 times faster than the replacement rate. This is while the rate is 30 to 40 times in India and China. [13] Soil is one of the most valuable capital of each country. If the use of soil is based on its potential and its production power, and based on the correct and scientific principles, the rate of soil loss is minimized. Erosion is the persistent exhaustion of the earth's surface soil by water or wind, in general, it can be said that erosion is taking and transferring soil particles from place to place, which may be carried out by water or wind. [24] Soil erosion is one of the most important factors in the degradation and reduction of soil fertility, which is increasing today and leads to the loss of good agricultural soil. Effective factors in erosion include climatic factors such as soil type, vegetation, and terrain features. [4]

One of the factors of erosion is the change in the use of pasture to dry farming. So, the rate of soil erosion is estimated at $400 \mathrm{~m}^{2} / \mathrm{s}$. Additionally, improper management of pastures and non-standard human activities, such as excessive grazing, burning bushes and tillage activities have caused the erosion in these lands. One of the consequences of land degradation is the reduction of vegetation and the destruction of the surface soil. [18] Soil erosion based on Universal Soil Loss Equation, is affected by factors such as rainfall erosion, soil erodibility, topography and vegetation. Soil erosion is the quantitative and qualitative technical expression of intrinsic sensitivity of the soil particles to separation and transfer by erosion factors. [21]

The rain, along with runoff shear force on the soil surface separates soil particles from their original bed, while runoff drives separated particles to the bottom of the slope. Therefore, it can be said that soil erosion is a function of the ability to separate soil particles from each other and transfer them. [25] Many studies have focused on the effect of different soil properties, including the degree of separation and transfer of soil

(C) 2019 Published by University Press. This is an open access article licensed under the Creative Commons Attribution-NonCommercial-NoDerivs License (http://creativecommons.org/licenses/by-nc-nd/3.0/). 
particles, or, in other words, its erosion. Studies on the effect of crushed stone on the amount of soil erosion show that the pebbles in the surface soil layer on the one hand, protect the soil from the impact of rain, which reduces soil erosion and increases the rate of roughness and prevents the transfer of soil particles. [14] Also, in a study by Poesen and Figueiredo showing that there is a negative exponential relationship between crushed stone on the soil surface and the rate of washed sediment, and there is a negative linear and time-varying relationship between this factor and the splashed sediment. [10]

In the study by Duiker et al., on soil waste, it was found that soil loss is strongly correlated with very fine sand and very fine sand with silt. [8]

If the soil clay content is less than $10 \%$, there will be almost no soil structure, and if a structure is made, it will not have much adhesion and will quickly disperse as a result of erosion, and the aggregate is usually found in soils with less silt. Another factor effective in soil structure as a result of soil erosion is cement materials, as well as calcium carbonate (lime), and iron and aluminum oxides are the factors stabilizing aggregates in the soil. $[8,6]$

The weighted mean of the aggregate MWD is a very good indicator for examining the stability of aggregates as well as the average diameter of aggregates in the soil. By increasing clay content, MWD significantly increases and calcium carbonate also increases MWD by 4\%. [1,2]

Another factor affecting soil erosion and its loss is topography and the characteristics of the earth gradient. In a study by Le Bissonnais and Chaplot in this area, it was found that runoff increases by increasing gradient percent. [7] In another study by Zhang et al., on Loess Plateau in China [12], it was shown that the percentage of earth gradient is the most important factor affecting runoff and soil loss. Battany and Grismer argue that an increase in the earth gradient between $4-16 \%$ has a positive significant effect on the soil in California. [3]

Another important factor in soil erosion is vegetation cover. Vegetation in different dimensions reduces the rate of soil erosion. Many studies have been carried out in this field and all believe that vegetation prevents water erosion. [9,11] The erosion factor is obtained from the rate of soil loss from standard plots per unit of rainfall erosion. The standard plot or unit plot is a land with a gradient of $9 \%$, width of 1.83 , and a length of $22.1 \mathrm{~m}$, ploughed in the direction of the gradient, and its surface lacks vegetation and its remaining, and no protective operations should be carried out in it. The density percentage factor is the vegetation cover percentage in the soil surface, or in other words, is the ratio of the soil surface covered with the vegetation to the total surface area of the soil against the corrosive factors of water, and it is one of the most important factors affecting the rate of erosion due to rainfall and runoff. The results of study by Morin and Kosovsky [17] and
Romero et al., [19] show that the rate of runoff and experimentation in small plots with low vegetation cover is far more than environments dense with vegetation. López-Bermúdez et al., [15] found that soil erosion in a plot full of stone and vegetation is far less than the erosion rate in a plot lacking vegetation or plowed. In another study by Battany and Grismer [3] and Wainwright et al., [22] the percentage of vegetation density is considered as the main factor limiting soil erosion.

\section{Soil Erosion}

Soil conservation means controlling factors affecting its erosion. Water erosion has a direct relationship with the rate of rainfall, the earth gradient and soil sensitivity to erosion (soil adhesion structure), and an inverse relationship with permeability and vegetation cover. Therefore, in order to reduce the water erosion, it is necessary to reduce the rate of rainfall, the earth gradient and the sensitivity of the soil to erosion. However, the rate of rainfall cannot be changed, but by providing suitable solutions, water erosion can be reduced to an acceptable level and vegetation can be increased. In wind erosion, soil erosion has a direct relationship with wind speed and soil sensitivity and has an inverse relationship with the vegetation. In order to reduce the rate of wind erosion, it is necessary to reduce wind speed and soil sensitivity to erosion and increase vegetation. Its speed can be reduced by building an obstacle on the wind path, and the soil can be protected against wind erosion by soil cementation and increasing vegetation.

\subsection{Different Forms of Erosion}

\section{A. Natural soil erosion}

It is a time-consuming and long-term process occurring on all soils at all times. This kind of erosion helps to form soil and distribute it on the earth surface and is in balance with the soil formation process. [5] In fact, the natural erosion is a process created very slowly since the formation of the earth, and it is still happening. On the one hand, it creates rich plains and for human nutrition by naturally rubbing the rocks, stones and valleys, and lands full of sediments and eroded soils. Therefore, the complete stop of this process is not logical and possible, but it should be tried to reduce it to an acceptable level. [20]

\section{B. Unnatural or exacerbating erosion}

This kind of erosion occurred since when human beings entered the realm of agriculture and animal husbandry. This erosion is more intense and faster than natural one. It occurs with human activity in nature, including changes in vegetation and soil conditions. Unnatural erosion involves the breakdown of aggregates, exacerbating displacement and transferring organic and inorganic materials as a result 
of inappropriate cultivating and plowing methods and destroying vegetation. [23]

\subsection{Different Types of Erosion}

\section{A. Water erosion}

This erosion is defined in such a way that the soil particles are flowing from their site with the help of water and deposit somewhere else. First, rain drops raining on the soil, which is called splash erosion, and then the soil particles run by runoff. When the water moves in the direction of the gradient, the soil particles are separated from each other and water erosion occurs.

There are three types of changes in erosion: first, the soil structure changes, which reduces soil fertility, then grooves, cavities and potholes create in the soil, which reduces the use of these points in the land, and ultimately soil deposits in a region which fills the reservoirs of dam, watershed, etc. But sometimes this sediment is useful and also forms the plain [16]

B. Wind erosion

In general, wind erosion refers to a phenomenon in which soil particles are transfer from place to place with a wind power. The wind erosion mechanism is as follows: the wind blows into the soil drying its humidity and, consequently, transfers it to another point. In wind erosion, two factors play an important role: wind force and topography of the region [23].

\section{Soil erosion prevention factors}

We spoke previously about the erosion, its mechanism and types, and now some strategies are proposed to reduce erosion.

is referred to a variety of measures and practices that enhance vegetation cover. The biological control operation itself consists of two parts.

\subsection{Biological control operations}

A. Prevention of forest and pasture erosion Some measures are done to control the soil loss and prevent erosion in forest lands and pastures as follows:

1. Forestry activities: Measures to protect soil from erosion by increasing and developing forest, including planting trees, not cutting trees and building paths for runoff, which prevent loss of Forest and or renovating the forest life.

2. Range management measures: it refers to measures to control and adapt the livestock with the capacity of the pasture to give the opportunity to grow plants.

B. Preventing erosion of agricultural lands Activities and measures to control the erosion of agricultural lands like:

1. Changing the plough direction, so that it is perpendicular to the gradient of the earth or in the plowing curve.

2. Remaining part of the plant residues on the soil after harvesting, which is intended to protect the soil.
3. Strip cropping: for preventing soil erosion and its loss, crop on the strips and lines constructed in the direction of plough.

4. Proper irrigation of agricultural lands and establishment of suitable irrigation streams to reduce soil erosion.

\subsection{Mechanical control measure}

In places where erosion is intense and the possibility of biological operations is difficult, mechanical actions should be taken, including channeling and benching in steep slopes, building obstacles and dams in front of the valleys, using windbreak and using mulching in on river route and the sea waves that the use of this type of operation, together with biological ones, will increase the level of resistance to soil erosion.

A. Preventing soil erosion by benching and channeling in slopping land

This action is used in sloping mountainous regions where the runoff transfer the soil above the slope down and cause severe erosion, so that the depth and distance of this channeling or benching depend on factors such as rainfall intensity, area of the region, soil erosion, land gradient and vegetation.

B. Building obstacles and dam in the valley areas to reduce soil erosion

In areas where soil erosion is very advanced, land becomes a valley where rainfall-driven water move rapidly and runoff is formed quickly to reduce water speed and runoff destructing force. Dam and obstacles are built on these valleys. The construction of these structures is carried out with materials such as concrete, and they are built on the path of valley as a series of successive steps and some plants are sowed behind these structures which reduce the runoff energy.

\section{Using a windbreak to prevent soil loss}

When the wind speed is so that it can carry the soil particles, it is called erosion threshold speed and when the wind speed reached the erosion threshold, it leads to wind erosion of the soil. To prevent this, the use of the windbreak is important and fundamental. The windbreak is usually in several rows perpendicular to the wind direction.

D. Soil erosion reduction by mulching

It is said to covering the soil surface by oil, gravel or vegetation residues, and this is in this way that the surface of the soil is covered with these materials and has a significant effect on preventing soil erosion, and the more the amount and density of the coverage, the less the erosion will be.

\section{Conclusion}

Soil is one of the most important natural resources in the world. Its preservation will lead to the life of the human community, and maintenance of it will contribute to the provision, prosperity and security of 
life. But today, soil erosion is very high due to various reasons. This research tried to describe and investigate various types of erosion and ways to prevent it. Finally, by creating biological and mechanical activities, it is possible to reduce the erosion to the desired level, and what is clear is the density of vegetation, the percentage of coarse gravel in the surface layer of the soil and the gradient of the earth are the most important factors in soil erosion, respectively. Based on the above, it is necessary to pay attention to the soil surface as an obstacle to natural rainfall collisions to reduce the potential for erosion and sediment production. Therefore, the enhancement and regeneration of vegetation, prevention of excessive livestock grazing, the use of pebble mulch on the soil surface, managing the land slope and reducing the length of steep slopes are solutions to reduce and prevent soil erosion

\section{References}

[1] Al-ani. A.N., Dudas.M.J., (1988), Influence of calcium carbonate on mean weight diameter of soil. Soil and Tillage Research, 11(1). pp. 19-26. doi.org/10.1016/0167-1987(88)90028-1

[2] Attou. F., Bruand. A., Le Bissonnais. Y. (1998), Effect of clay content and silt-clay fabric on stability of artificial aggregates. European Journal of Soil Science, 49, pp. 569-577. doi.org/10.1046/j.1365-2389.1998.4940569.x

[3] Battany, M.C., Grismer. M.E., (2000), Rainfall runoff and erosion in Napa Valley vineyards: effects of slope, cover and surface roughness. Hydrological Process, 14(7), pp. 1289-1304. https://doi.org/10.1002/(SICI)10991085(200005)14:7<1289::AIDHYP43>3.0.CO;2-R

[4] Bouaziz, M., Leidig, M. Gloaguen, R. (2011), Optimal parameter selection for qualitative regional erosion risk monitoring: A remote sensing study of SE Ethiopia, Geoscience Frontiers, 2(2), pp. 237-245. doi.org/10.1016/j.gsf.2011.03.004

[5] Camp, N.G., Daugherty, T.B. (2002), Managing Our National Resources $3^{\text {rd }}$ Edition. Delmar, NewYork, USA.

[6] Cerda. A. (1996), Soil aggregate stability in three Mediterranean environments, Soil Technology, 9(3), pp. 133-140. doi.org/10.1016/S09333630(96)00008-6

[7] Chaplot. V., Le Bissonnais. Y. (2000), Field measurements of interrill erosion under different slopes and plot sizes, Earth Surface Processes and Landform, 25, pp. 145-153. doi.org/10.1002/(SICI)10969837(200002)25:2<145::AID-ESP51>3.0.CO;23

[8] Duiker. S.W., Flanagan. D.C., Lal. R. (2001), Erodibility and Infiltration characteristics of five major soils of southwest Spain, CATENA 45(2),
103-121.

8162(01)00145-X

[9] Elwell. H.A., Stocking, M.A. (1976), Vegetal cover to estimate soil erosion hazard in Rhodesia, Geoderma, 15(1), pp. 61-70. doi.org/10.1016/0016-7061(76)90071-9

[10] Figueiredo. T.D., Poesen. J. (1998), Effect of surface rock fragment characteristics on interrill runoff and erosion of a silty loam soil. Soil and Tillage Research, 46(1), pp. 81-95. doi.org/10.1016/S0167-1987(98)80110-4

[11] Francis, C. F., Thornes, J. B. (1990), Runoff hydrographs from three Mediterranean vegetation cover types. Vegetation and erosion. Processes and environments. pp. 363-384.

[12] Kang. Sh.,Zhang. L., Song. X., Zhang. S., Liu. X., Liang. Y., Zheng. S. (2001), Runoff and sediment loss responses to rainfall and land use in two agricultural catchments on the Loess Plateau of China. Hydrological Process, 15(6), pp. 977-988. doi.org/10.1002/(SICI)10969837(200002)25:2<145::AID-ESP51>3.0.CO;23

[13] Lang, S.S. (2006), 'Slow, insidious' soil erosion threatens human health and welfare as well as the environment, Cornell study asserts.

[14] Li. X.Y. (2003), Gravel-sand mulch for soil and water conservation in the semiarid loess region of northwest China. Catena, 52(2), pp. 105-127. doi.org/10.1016/S0341-8162(02)00181-9

[15] López-Bermúdez, F., Romero-Díaz, A., Martínez-Fernandez, J., Martínez-Fernandez, J. (1998), Vegetation and soil erosion under a semiarid Mediterranean climate: a case study from Murcia (Spain), Geomorphology, 24(1), pp. 5158. doi.org/10.1016/S0169-555X(97)00100-1

[16] Martínez-Zavala, L., Jordán-López, A., Bellinfante,N. (2008), Seasonal variability of runoff and soil loss on forest road backslopes under simulated rainfall, CATENA, 74(1), pp. 73-79.

https://doi.org/10.1016/j.catena.2008.03.006

[17] Morin, J., Kosovsky, A. (1995), The surface infiltration model, Journal of Soil and Water Conservation, 50, pp. 470-476.

[18] Ravi, S., Breshears, D.D., Huxman, T,E., D'Odorico, P. (2009), Land degradation in drylands: Interactions among hydrologic32eolian erosion and vegetation dynamics, Geomorphology, 116(3-4), pp. 236-245. doi.org/10.1016/j.geomorph.2009.11.023

[19] Romero-Díaz, A., Cammeraat, L.H., Vacca. A., Kosmas, C. (1999), Soil erosion at three experimental sites in the Mediterranean, Earth Surface. Processes and Landform, 24(13), pp. 1243-1256. doi.org/10.1002/(SICI)10969837(199912)24:13<1243::AIDESP43>3.0.CO;2-Z 
[20] Schwab, O.G., Fangmeier, D.D., Elliot, W.J., Frevert, R.K. (2016), Soil and Water

[21] Vaezi A.R., Bahrami H.A., Sadeghi Hamid Reza, Mahdian M.H. (2008), Etermining the estimating error of usle erodibility factor in calcareous soils of Northwestern Iran, Journal of Water and Soil (Agricultural Sciences and Technology), 22(2), pp. 61-72.

[22] Wainwright, J., Parsons A.J., Abrahams, A.D. (2000), Plot-scale studies of vegetation, overland flow and erosion interactions: case studies from Arizona and New Mexico, Hydrological Process 14(16-17), pp. 2921-2943. https://doi.org/10.1002/10991085(200011/12)14:16/17<2921::AIDHYP127>3.0.CO;2-7

[23] Yang, S., Lianyou,L., Ping, Y., Tong, C. (2005), A review of soil erodibility in water and wind conservation Engineering( $6^{\text {th }}$ Edition), John Wiley \& Son, New York, USA.

erosion research, Journal of Geographical Sciences 15(2), pp. 167-176. DOI.10.1007/BF02872682

[24] Zangiabadi, M., Rangavar, A., Rafahi, H.Gh., Shorafa, M., Bihamta, M.R. (2010), Investigation of the most Important Factors Affecting on Soil Erosion in Kalat Semi-Arid Rangeland, Journal of Water and Soil, 24(4), pp. 737-744.

[25] Zhang, K.L., Shu, P., Xu, X.L. Yang, Q.K., Yu, B. (2008), Soil erodibility and its estimation for agricultural soils in China, Journal of Arid Environments, 72(6), pp. 1002-1011. doi.org/10.1016/j.jaridenv.2007.11.018 